\title{
脳血管障害後片麻痺患者にみられる 膝の変形性変化について
}

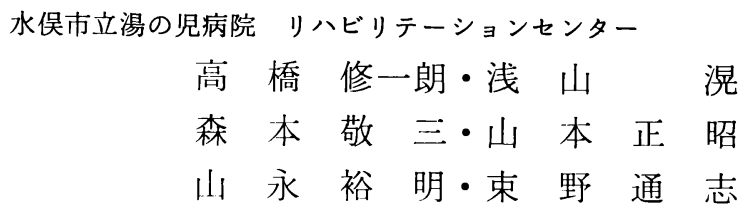

\section{Osteoarthritic Changes of the Knee in Hemiplegic Patients}

\author{
by
}

\author{
S. Takahashi, K. Asayama, K. Morimoto, M. Yamamoto, \\ H. Yamanaga and M. Tsukano \\ Yunoko Byoin Rehabilitation Center Minamata Municipal Hospital
}

\begin{abstract}
The patients with hemiplegia were investigated if they have some trouble in their knees or not. Of twenty-eight hemiplegic in-patients, ten $(35 \%)$ had painful knee, nineteen $(67 \%)$ had osteoarthritic changes at involed side. Osteoporotic changes were seen in most patients. OA changes were seen with greater frequency in patients with duration of seven months or more than those of six months or less. And those changes were seen more frequently in wheelchair group than in ambulatory one. OA changes were not related with spasticity or sensory disturbance. $(p>0.05)$. Discussion was made about these findings.
\end{abstract}

\section{はじめに}

脳血管障害 (以下 CVA と略す) 後片麻㾝患者で は, 患側の痙性, それに伴う足部変形や反張膝, 知覚 障害等の後遗症状を呈する例が多い，乙のような症状 は, 膝関節への異常な負荷となり, 変形性変化を惹起 するのではないかと考えられる.

実際, 本症患者のリハビリテーションに際し, 膝関 節痛を訴える例が少なくない。

そこで, 今回, 膝関節痛及び変形性変化 (以下 $\mathrm{OA}$ と略す）の実態を調べると共に，本症患者の持つ種々 な病的因子が，その発生にどのように関与しているか を検討したので報告する.

\section{対象と方法}

対象は, 当院入院中の本症患者の中, CVA 発症以 前には, 膝関節痛, 或いは, 膝への外傷等の既往のな い28名とした（表 I ）.
表 I 症 例

\begin{tabular}{|ccc|}
\hline 男 20 人 & 女 8 人 & 計 28 人 \\
右片麻㾝15人 & 左片麻痒 13 人 & \\
年令25 80 才 & 平均60才 & \\
\hline
\end{tabular}

この 28 名につき, 昭和 52 年の 日整会試案に準じ て, 膝関節機能評価を行なった.レ線学的には, 立位 正面像, 側面像, 及び Skyline View を用いた.

$\mathrm{OA}$ 変化発生に関与し得る因子として, 発作から検 查時までの期間, 下肢 Brunnstrom Stage 歩行能 力, $\mathrm{ROM}$, 座性, 下肢变形, 知覚障害等を取りあげ た.

\section{結果}

I . 膝関節痛及びOA 変化の有無

28 例中, 患側のみに痛みある者 8 例, 健側の みに ある者 1 例，両側共にある者 2 例であった（表 II）.

レ線上，患側では 24 膝 (86\%) に骨粗鬆を認め, 
表 II 滕関節痛の有無

\begin{tabular}{|c|c|c|c|c|c|}
\hline 疼 & 痛 & 部 & 位 & 例 & 症 \\
\hline $\begin{array}{l}\text { 患 } \\
\text { 健 } \\
\text { 両 }\end{array}$ & $\begin{array}{l}\text { 側 } \\
\text { 側 } \\
\text { 側 }\end{array}$ & $\begin{array}{l}\text { の } \\
\text { の } \\
\text { と }\end{array}$ & $\begin{array}{l}\text { み } \\
\text { み } \\
\text { む }\end{array}$ & $\begin{array}{l}8 \\
1 \\
2\end{array}$ & \\
\hline \multicolumn{4}{|c|}{ 計 } & 11 & \\
\hline
\end{tabular}

（28例中 11 例 $40 \%$ 近くに痛みあり）

表 I $レ$ 線 所兄

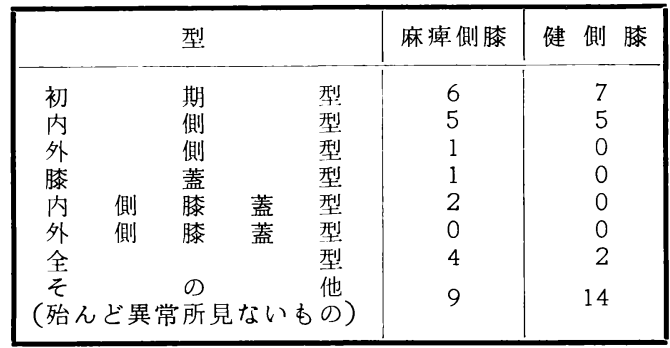

両側に認めるのは，21例であった. この中，15例で 患側の方がより高度な変化を呈していた.

FTA は，健側と患側とで，差を認めなかった．患 側のみについてあ， OA変化の有無による FTA の 差はなかった（p>0.05）.

O A 変化は，患側で 19 例 $(68 \%)$ ， 健側で 14 例 （50\%）に認めた. 両者間に有意差はない（p> 0. 05).

また関節裂隙狭少化の部位により，O A変化を分類 すると，表 IIIの如くなる.

II . 各因子との関係

(1) 䍜病期間について

患側について, 発作後 6 力月以内の例之 7 力月以上 の例とを比べると, 7 カ月以上の例にO A変化の発生 が大であった. しかし，患側と健側との間を比較して みると, 䍜病期間による $\mathrm{OA}$ 変化の有意差はなかった (p>0.05).

(2) 下肢 Brunnstrom Stage について stage III 以上と II 以下とに分け，それぞれについ て, 患側及び健側の O A 変化発生を比較すると, 両者 間に差はなかった．また患側のみについても，而以上 とII 以下とで差を認めなかった.

（3）歩行群と車椅子群について

それぞれの群におけるO A変化の発生を, 患側と健 側とで比べると，差は認めなかった．乙れを患側のみ
についてみると, 歩行者群に比べ, 車椅子群の方に, $\mathrm{O}$ A変化発生がより多く認められた $(\mathrm{p}<0.05)$.

(4) 可動域について

殆んど全例 passive ROM は正常範囲にあった. しかし，本症のような中枢性神経疾患においては，静 的状態での passive ROM と動的状態での active ROM とでは，その意義が大きく異なることから，日 常生活時, 例えば歩行時等の active ROM を測定す る必要があろう.

(5) 痙性について

at rest での痙性の程度とO A変化の発生とをみる と，患側と健側とで，差は認めなかった．患側のみに ついてみても, 痤性の程度と O A変化とに, 相関関係 は認めなかった。

また, 痤性高度例のみについて, 䍜病期間とO A 変 化の発生とを比較したが，相関関係は認めなかった。

(6) 下肢変形について

尖足が 13 例にみられ，そのうち 3 例は明らかな反 張膝を呈した.

尖足を呈する例 の O A 変化発生は, 患側と健側之 で，差を認めなかった．患側のみについてみても，尖 足の有無とO A変化発生とに関係を認めなかった.

(7) 知覚障害について

知覚障害を有する例の $\mathrm{OA}$ 変化発生は, 患側と健側 とで差を認めなかった．患側のみについてみても，知 覚障害の有無とO A 変化発生とに, 関係を認めなかっ た.

考 察

CVA による片麻㾝患者 28 例 56 膝を調べたとと ろ，膝関節痛及びO A 変化を認める例が多かった．更 に，それは健側に比べ患側により多く認められた.

このことは，麻㾝による種々の病的要因が膝関節の $\mathrm{O} A$ 変化に対し, 何らかの関与をしていることを, 示 唆するあのである.

そこで, 病的状態として捉えられる後遺症状の中, 痤性, 下肢変形, 或いは知覚障害等がその主な因子で はないかと考え，検討を加えた. しかし，予想に反 し，これらについては，OA変化発生との間に，相関 関係を見付けることができなかった。

骨粗鬆症は，患側に多く且つ高度に認められたが， 健側にも高率に認められた。本症患者は他疾患患者に 比べ，活動性が低いことが指摘されており，乙の所見 
も，活動性低下による廃用性萎縮と考えられる。

荷重機会が多い程, O A 変化が高率に起こるのでは ないかと考えた. しかし結果的には歩行群に比し，荷 重機会の少ない車椅子群により多くのOA変化の発生 を認めた。 てれは車椅子群の平均年令が 10 才以上も 高かったととが，その一因と考えられる.

また，今回の調査では，対象者の性質上，下肢変形 を呈する例が多かったのは当然のてとであるが，膝の $\mathrm{OA}$ 変化発生との関連は認められなかった.

痤性, 下肢変形, 更に知覚障害等の程度についての 左右差がみい出されなかったが，本来ならば，当然こ れらは膝の変形に関与する因子である．長期枚病例が 少なかったとはいえ，片麻㾝患者の日常生活動作が大 変低下しており, time study における歩行動作の合 計時間が少ないととを裏づけているすのと推定され る.

尚，尖足について言及すると，その高度な例には Vulpius 法を用いて改善を図っている。 しかし，本 症患者では, 歩行の安定ということから, knee locking の方が具合が良い一面ああり，反張膝について は，それが高度となるととでリ八阻害因子とならない 限り, 許容している.

\section{ま と め}

1. CVA 後片麻㾝患者 28 例 56 膝につき, 疼痛及 びO A変化の有無を調べ，更に種々な要因と，膝関節 症状との関連を調べた.

2. 11 例に膝関節痛を認めた

3. 19 例に患側の O A 変化を認めた.
4. 殆んど全例に，骨粗鬆を認めた.

5. 患側の $\mathrm{O} A$ 変化は, 罹病 7 力月以上の者に, ま た, 歩行群より車椅子群に, 多く認められた.

6. O A 変化の発生は, 痙性の強さや知覚障害の程 度には，関係なかった。

7. 概して, CVA 患者の日常生活では, 歩行動作 の時間が大変少ないととが示唆された.

\section{文献}

1）伊勢亀富士朗・他：臨整外，10：303，1975。

2）伊勢亀富士朗・他：臨整外，11：908，1976。

3）伊勢亀富士朗 - 他：整形外科，27：961，1976。

4）伊勢亀富士朗・他：臨整外，12：639，1977。

5）小林 晶・他：整形外科, $29: 753,1978$.

6）小林 晶・他：臨整外， $14: 26,1979$.

7）二八宮節夫・他：臨整外，14：10, 1979.

8）岡本連三・他：臨整外，12：850, 1977.

9）岡本連三・他：臨整外，14:235, 1979 .

10）新野徳・他：臨整外，13：832, 1978.

質 問 鳥大整形 䲐 俊朗 歩行可能な片麻㾝患者で特に Spasticity が高い患 者の P-F の問題で, 滕蓋骨高位のあるあのあ, dislocation をとあなう症例はありませんでしたか.

\section{回 答}

(1) 膝蓋骨高位については計測を行なっていません。

(2) dislocation を認めるものは 1 例むありませんで した. 